\title{
HERBERTO HeLDER: DA CONDIÇ̃̃O ABSOLUTA DA POESIA MODERNA
}

HERBERTO HELDER: ON MODERN POETRY ABSOLUTE CONDITION

http://dx.doi.org/10.11606/issn.2175-3180.v12i22p47-75

Fernando Jorge Oliveira Ribeiro ${ }^{\mathrm{I}}$

RESUMO

Da original modernidade na poesia de $\mathrm{H}$. Helder: 1- Defesa da poesia de E. Bettencourt por H. Helder; 2- "Orpheu” e a defesa da sua modernidade revolucionária por H. Helder e E. Lourenço; 3- Para uma definição de poesia moderna de $\mathrm{H}$. Helder por "Ein Brief" (Uma Carta) de Hugo von Hofmannsthal; 4- Para uma definição de poesia moderna.

\section{PALAVRAS-CHAVE}

Poesia; Modernidade; Photomaton \& Vox; Introdução a Edmundo Bettencourt por $\mathrm{H}$. Helder.

\section{ABSTRACT}

On H. Helder's poetry and its modernity and originality: 1- Helder's praising E. Bettencourt's poetry; 2-Helder's and E. Lourenço's apology of the revolutionary features of "Orpheu" 's literary modernity; 3- On the definition of modern poetry Helder's with the help of H. $v$. Hofmannsthal's "Ein Brief"; 4- On a definition of modern poetry.

\section{KEYWORDS}

Poetry, Modernity, Helder's Photomaton EVox, Introduction to Edmundo Bettencourt's Poetry.

\footnotetext{
I Universidade Nova de Lisboa, Lisboa, Portugal.
} 
1: EM POESIA TODA DE HERBERTO HELDER, publicada em dois volumes em 1973, registramos coligidas em seu I volume: "A Colher na Boca" (195360), "Poemacto" (1961), "Lugar" (1961-2); “O Bebedor Nocturno" (196166). Desta última, constam "Poemas Arábico-Andaluzes"1 de dezassete poetas arábico-andaluzes cujos poemas, em prosa curta, ostentam título em português e autoria entre parêntesis curvos. Dezasseis estão representados com um poema cada, à excepção de Ben Jafacha ( Ibn Jafacha: 1058-1139), de cuja obra Helder selecciona três: “O Rio", “O Nadador Negro" e "O Cavalo Alazão". Helder não refere se os traduziu do árabe, mas deixa perceber quanto seu fascinante processo de criação poética radica em e poderá ser explicado pela replicação deste modelo de adopção de cenas de realidade imaginada. A atenção do leitor fica aparentemente concentrada na descrição de realidade comummente aceitável, porque acredita estar frente a mera descrição idílico-romântica de realidade referencial ao perceber o circunscrever abrangente de realidade de cor e movimento associados a personagem em meio da natureza seleccionada por sensibilidade do criador; assim persuadido por inusitada, hiperbólica e/ou pleonástica beleza, mal suspeita, ainda que apenas subtil e paulatinamente, mesmo por excesso ou por defeito, estar seu deslumbramento sendo objecto de composição que culminará em visão derradeira original. Em "O Rio" vê-se respectivo percurso desde o seu correr fresco em leito, às voltas em meandros bordejados por flores, à largueza ou estreiteza cuja imagética apenas putativamente descritiva se denuncia por comparações enquanto exercício literário, pelo qual se desvia o leitor do universo empírico do homem amante, do adorno feminino, do atavio ou do traço em rosto. Veja-se em "O Rio": "Belo deslizava o rio no seu leito,/(...) curvado como pulseira/(...) até parecer um pesponto de prata numa túnica verde/(...) cercavam-no os ramos como pestanas" (HELDER 1973, p. 265). Assim toda a significação do poema arrematado em sexta parte (em seis) e último e quinto parágrafo (em cinco) e seus dois últimos versos, nos quais a macro visão se torna micro porquanto correnteza de rio e reverberações a este associadas, e apresentadas em partes anteriores, se

${ }^{1}$ Em “O Bebedor Nocturno" (1961-66) H. Helder inclui também poemas indochineses, árabes, zen, do antigo Egipto, do Antigo Testamento a par de canções do Épiro, escocesas, de camponeses do Japão, de esquimós, dos pele-vermelhas e ainda "Enigmas Mayas" e "Enigmas Aztecas". 
convertem em visão de eu poético servindo vinho a seus convivas atento simultaneamente a reverberações e associações produzidas por luz em superfícies de enaltecida contiguidade já que oferecendo chave para reinterpretação de imagens anteriores, como em "O Rio": "Enquanto na margem eu distribuía vinho dourado cujo reflexo/Mordia as mãos dos convivas." (HELDER, 1973, p. 265). Em “O Nadador Negro" vê-se lago em cuja limpidez azul de águas nada negro para desde logo se salientar contraste entre luminosidade englobante e respectiva ausência pontual e dinâmica: "Tinha o lago a forma de uma pupila azul de que o negro era a menina do olho" (HELDER, 1973, p. 266).O desvendar deste imagismo corrobora o deslumbramento que o receptor assim sugestionado assimila ao humor cuja distanciação Helder aprecia e faz apreciar, levando o leitor a re-ver realidade coeva com outro olhar. Em "O Cavalo Alazão" vê-se batalha de encarniçada intensidade em cujo centro cavalo lazão se destaca, pleonasticamente, com suas crinas naturalmente avermelhadas e orelhas ágeis e diminutas: "Era um cavalo alazão, e à sua volta a batalha (...) As crinas eram cor da flor da romanzeira" para reforçar intrepidez traduzida por hipálage: 'tição de coragem' e assim salientar contraste entre metonímica singularidade: alazão (e seu ginete, liderantes), ou seja, centro em pluralidade - informe massa - em peleja tal qual: “(...) abria-se uma estrela branca, como as bolhas claras que nascem numa taça de vinho rubro." (HELDER, 1973, p. 266). Nestes poemas em prosa a inicial linearidade poética enviesa-se à medida que o curso da descrição se transforma em visão inédita o que sucede em último dístico o sexto, o segundo e o terceiro em cada um destes três poemas respectivamente para que, pelo humor, o criador de acrescida fantasia deslumbre o leitor e o leve a reconhecer capacidade de reinterpretar o real quotidiano colectivo com recurso à imaginação criadora. A preferência por Ibn Jafacha permite-nos afirmar que em qualquer dos três poemas dilectos a visão panorâmica cede a redução de campo. O rio é comparado ao vinho dourado vertido em taças, o lago à pupila azul, a estrela branca em peito do alazão às bolhas claras em vinho tinto. Helder, precisamente em texto poetológico antecedendo poemas de "O Bebedor Nocturno" explicita sua ars poetica (HELDER, 1973, p. 210). Defende a "regra de ouro (...): liberdade" (HELDER, 1973, p. 210) - presume-se liberdade poética cultivada quer por leitor quer por criador; permite se infira quanto em si próprio tentou realizá-la, vertendo-a em sua criação poética (HELDER, 1973, p. 210). 
Reconhece sentir-se devedor de "sentido emocional, mental, linguístico" havido em momento subreptício de interacção com poema em língua inglesa, francesa, italiana ou espanhola. Independente, mas conscientemente, de criações poéticas consultadas, Helder apenas reconhece como poema o seu - outros, como o caso destes, serão origem de um seu que logo se autonomiza por via de "explosão" literária condicionada pelo "prazer" obtido ao ajustar a gosto "(...) a temperatura da imagem, a velocidade do ritmo, a saturação atmosférica do vocábulo, a pressão do adjectivo sobre o substantivo." (HELDER, 1973, p. 210). Helder reconhece não saber todas as línguas, mas seguramente algumas; tal permitiu-lhe "(...) verter poesia do Antigo Egipto, desconhecendo o idioma, para o português." (HELDER, 1973 p. 209). Como o consegue? Procurando a translação, não a tradução: "Já me aconteceu imaginar a vida acrobática e centrífuga de um poliglota. (...) Vive das significações suspensas , da fascinação dos sons que convergem e divergem (...) cheio de malícias linguísticas. (...) é um verdadeiro irrealista (...)." (HELDER, 1973, p. 209). Remete-se à influência deixada pelo estímulo gerado pela prosódia idiomática; o poema originalmente torna-se seu, porque "recriação" e logo "versão indirecta"; resulta de "prazer" seguro e evidente pela e em composição tão mais poderosa quanto forma aberta de recriação potenciável por receptor: “(...) procuro construir o poema português pelo sentido emocional, mental, linguístico que eu tinha, sub-repticiamente, ao lê-lo em inglês, francês. italiano ou espanhol."(HELDER, 1973, p. 210). Justamente em inícios da década de sessenta do século XX, Helder escreveu texto intitulado "Relance sobre a Poesia de Edmundo Bettencourt" (1963), ao longo do qual afronta quer a criação literária dos autores alinhados com escritores em torno quer de Presença quer de Novo Cancioneiro e respectivo culto do Neo-realismo coevo como atitude preponderante de resistência político-cultural ao regímen salazarista. Este relance cumpre a função de despertar o interesse colectivo por "umas duas dúzias de poemas soberanos" (BETTENCOURT, 1999, p. 27) de Edmundo Bettencourt (1899-1973); faz-se acompanhar de post-scriptum elucidativo e contextualizador guarnecendo, trinta e seis anos mais tarde, edição de Poemas de Edmundo Bettencourt (1999). Nesta, Helder combate quer a ancilose das escolas dos "maîtres à penser" do passado quer o "analfabetismo democrático" coevo, denunciando "não-analfabetos" letrados e ineptos incapazes de acarinhar cultores da poesia resultante 
daquilo que se "esperava ser pegado e visto pelos lados de dentro" e que em 1999 ainda subestimavam criação poética moderna que se sabia "exorbitando" (BETTENCOURT, 1999, p. 28-9). Detalhes valiosos, quer cronológicos a serem assimilados pela história literária quer poetológicos de relevo por caracterizarem a criação literária em sequência de modernidade em Portugal do século XX, são defesa fundamentada da modernidade literária evidente na poesia de E. Bettencourt já em década de trinta do século XX. Pelos apreciados poemas-mentor arábicoandaluzes, aperceberamo-nos do valor da obra poética moderna desde cedo enaltecida por Helder, para quem a obra poética moderna é espaço de realidade autónoma da referencial cuja verdade não carece ser comprovada por realidades sociológicas e/ou outras; para Helder, a criação literária da modernidade não deixa mesmo assim de oferecer verdade, por muito que valores acolhidos por contextos humanistas, éticos, históricos entre outros não constituam igualmente seu escopo preponderante. A realidade imagético-emocional-insólita será espaço literário almejado, no qual receptor constatará o tirocínio da imaginação como forma em si própria potenciadora de corte com o real e de promitente inacessibilidade imediata ao imaginado: "A noção do poema como uma vida, organismo com leis específicas e realidade autónoma, é possivelmente a mais revolucionária proposta da lírica moderna" (BETTENCOURT, 1999, p. 18). Não admira por isso se constatem semelhanças entre criações literárias de "O Bebedor Nocturno" (1961-66) de Helder e "Poemas Surdos" (1934-40) de Edmundo de Bettencourt; com estes Helder confessa emocionar-se deveras (BETTENCOURT, 1999, p. 17), por ver contribuir técnica de insistente deformação, distensão, potenciada por perspectiva anamórfica, para nova praxis poética. Nos poemas arábico-andaluzes observámos o quanto a partir de último dístico se revê o real aparentemente fielmente descrito e reconhecível à luz de outra perspectiva: receptor rende-se, desprevenido, ao afastamento do real reconhecível e à aproximação de realidade icognoscível assente, para sua sobrevivência, em vivência de entidade outronímica transformadora o bastante de cultura inatenta a tais técnicas de prospecção de: 1- realidade fantástica; 2- discurso literário inédito. Ambas fazem jus a capacidade de composição e reformulação sobre matéria-prima, i.e., linguagem geradora de linguagem emergente e de seu ingente universo de significações. A criação poética serve o corte com o uso de palavra subserviente e instrumento de evidências esperadas: 


\begin{abstract}
Que a verdade está na imaginação não seria descoberta nenhuma, mas procurar que a própria imaginação deixe de contar com a tradição da realidade para a conquista de uma verdadeira vida e que (sobretudo isso) a imaginação encarregue o poema de realizar o acto de um corte decisivo com os princípios do humanismo e da experiência histórica do sentimento, da ética e da cultura - é algo soberbamente arrojado. (BETTENCOURT, 1999, p. 18)
\end{abstract}

No discurso poético da modernidade e a exemplo de obra de Bettencourt, Helder vê o carácter revolucionário na ausência de narrativismo, tal qual acabámos de constatar de suas palavras em «Relance sobre Poesia de Edmundo de Bettencourt»; este será inversamente proporcional à expansão de universo de multivocidades em virtude de os nexos não se submeterem à causalidade lógica, mas à associação e à analogia que procuram dar forma às emoção e imaginação determinantes em vertente apenas inicialmente pessoal. O novo real nascerá de apontamento de exacerbada ambiguidade, espaço de amplos limites, no seio do qual se jogam complexidades e densidade que vão evoluindo à medida que as imagens do quotidiano, imaginado ou sobre-imaginado, são levadas intencionalmente à exaustão destruidora do escopo funcional incluso em toda a palavra. Todavia o criador literário moderno é desafiado a conseguir manipulação exímia da palavra para construir edifício novo com elementos singulares em interacção conjugados como formas verbais para gerarem dinâmica na significação, assim conduzindo ao renascer incessante de novas significações. Não terá o deslumbramento assinalado em poemas arábico-andaluzes origem na rendição à simplicidade e originalidade conseguidas por Helder por haver realizado "imagismo" de clara excelência? Em tal criação poética, o convocar de elementos singulares não acontece por obediência a tema ou ideário previamente estabelecido, mas por técnica de fragmentação, aparentemente atomizada e carente de unidade, e por insinuação co-nexa, anunciadora de significação profunda, muito para além de significado usual de palavras subserviente a descrição figurativa; a inteligibilidade derradeira resulta afinal segundo uma outra ordem: a da insubmissão marginal ao estabelecido e esperado - assim fazendo com que todo o inédito tenha: "sentido mais moderno (...) por os seus nexos serem mais de sugestão que de narração." (BETTENCOURT, 1999, p. 16). Toda a realidade, aparentemente descrita obedecendo a putativo narrativismo, ganha outro estatuto por ser em conclusão de criação poética que a "imagem (...) 
conduzirá o poeta aos domínios da analogia" (BETTENCOURT, 1999, p. 17) forjando "consciência de inéditas dimensões" da nova realidade cujo carácter literário se plasma na forma poética porquanto entendida como o próprio real concreto, e em si próprio, absoluto. $\mathrm{O}$ real do poema perdeu os vínculos de referencialidade e a obra ao vingar como irrealista passou a resistente à realidade quotidiana e respectivas vicissitudes. A imaginação reforça o seu estatuto gerando, no campo da expressão, formas infinitas modernas sem temer correr qualquer risco de comunicação - não é este o seu interesse imediato. Com erudição, Helder cita Hugo Friedrich (19041978) teórico literário germânico, sobre o valor destas peculiaridades na configuração da modernidade: "a paixão pela transcendência converte-se em destruição cega da realidade. (...) signo caótico da insuficiência do real em geral, (...). Eis o que se pode chamar a dialéctica da modernidade." (BETTENCOURT, 1999, p. 19); também alude à modernidade em Rimbaud (1854-1891), enquanto poeta criador de espaço literário "libertário", "despistante" e resistente à cultura estática, racional, institucional : pretende seja transposta "noção tradicional de realidade"; e seja destacada realidade promotora da unidade do espírito sob exercício de imaginação: “(...) poeta moderno, é surrealista (...) agente recuperador de um mundo que a cultura atraiçoou." (BETTENCOURT, 1999, p. 21). Também se aproxima da poetologia dos românticos alemães ao salientar a pertinência de meta-realidade (BETTENCOURT, 1999, p. 16) iluminadora da vulgar por tomar aquela tão-só por absoluta: “(...) não somente que a 'poesia é o real absoluto' do romantismo alemão, mas que é um absoluto real e que o poema é a realidade desse absoluto." (BETTENCOURT, 1999, p. 20). A realidade única do poema moderno é assim também oferecida ao receptor como instrumentário de interpretação, ao longo de cujo discurso ganha forma universo de significações sentidas e tácitas em leitor hodierno. Claro o objectivo de fortalecer consciência de resistência aos demais: "O homem escreve um poema para se opor à vida e ao mundo, (...) não se trata aqui sequer de considerar a liberdade individual do artista, mas de ser justo e inteligente para com o espírito humano." (BETTENCOURT, 1999, p. 15). Helder reconhece valor literariamente revolucionário a Edmundo de Bettencourt por neste se ilustrar, em plena época entre pré I Grande Guerra e a morte de Pessoa, praxis de criação literária moderna assentando em profundo acto-de-imaginação individual, anti-moralista, anti-edificante e anti-instituição social e 
necessariamente anti-encomenda social mantendo-se apenas unicamente fiel ao daemon interior inerente a criador não-alinhado em debate permanente com a sua própria originalidade: “O homem escreve um poema (...), para negar o poder dos homens e libertar aquele 'daemon' interior que, ao mesmo tempo que indica uma tensão criadora, manifesta igual tensão destruidora." (BETTENCOURT, 1999, p. 15). "Poemas Surdos" ostentam liberdade poética vanguardista por ter sido conseguida muito antes que a de Mário Cesariny ou de António Maria Lisboa; tal individualidade criadora assente no movimento que a energia conseguida pela palavra geradora de vórtice de significações provoca na sensibilidade no receptor. Eis aqui a pedra de toque da actividade artística moderna: "o movimento é qualidade da imaginação (...) atributo da individualidade (...). Revolucionar equivale a imaginar, a ser individual." (BETTENCOURT, 1999, p. 13). Nos alucinantes "Poemas Surdos" (1934-40) destacamos imagismo exuberante dando voz a este movimento cuja energia desafia a imaginação do leitor a confrontar-se com significados inusitados por mão de metáforas inéditas e aplaudidas por poucos contemporâneos como por exemplo em "A Força do Olhar": “(...)/A força da fuga do olhar,/à vossa moribunda vibração,/vem de encontro ao nosso peito,/cai violenta sobre a falsa luz,/ataca violenta o falso dia./(...)" (BETTENCOURT, 1999, p. 141); ou em "Asas": “(...)/A cara dela/Que era uma sereia/E que era uma pantera a rebolar no chão/Aos rugidos metálicos do amor/Sob a forma de nuvens muito ao longe... (...)"(BETTENCOURT, 1999, p. 145): Ou "Espelho" que, em prosa, não perde a verve que tanto atrai Helder: "(...) ...E onde a tua boca,/com beijos quentes e perfeitos , era um caminho de águas e/avencas ao meio do fogo (...)" (BETTENCOURT, 1999, p. 151); sublinhem-se as raízes inconscientes de todas as metáforas que provocam a libertação de verbo ansioso pela modernidade anunciada e inatendida por correcta cultura dominante ou resistente cultivadas. Constate-se quanto logo na década de trinta do século passado Bettencourt se erigia como revolucionário, iconoclasta convicto de tradição redutora, e anti-escola ou qualquer outra instituição tão retrógrada quanto o sistema de que se distanciava.

\section{2: O VANGUARDISMO CONSTATADO EM BETTENCOURT decorrerá da} modernidade sabida originalmente vislumbrar na geração de Orpheu como denuncia Helder: 
(...) a geração posterior a Orpheu, em vez de criar a atmosfera propícia ao desenvolvimento dos princípos revolucionários contidos nele, veio atrasar de muitos anos a frutificação do exemplo. (...) deste modo se foi relegando para um futuro que nos deseuropeizava a recuperação de uma modernidade viva. (BETTENCOURT, 1999, p. 10)

Consequentemente não tomará grupo de escritores em torno da Presença como legatário da modernidade que observou, entre outros, em Pessoa - recorde-se Orpheu em cujos primeiro e segundo números (1915) se publicaram "Opiário" ou "Ode Triunfal" ambos de 1914 e "Ode Marítima" (1914), respectivamente. Enaltece por isso visão-de-futuro de Bettencourt por ter elevado a exigência e levado por diante voz outronímica contra escrita de base inteligível-humanitarista e sentimental em Presença (BETTENCOURT, 1999, p. 10). Tão pouco considera satisfatório, deste ponto de vista, o tardio aparecimento do surrealismo praticado por Antórnio Maria Lisboa e Mário Cesariny - valorizando por igual pouco a criação literária neo-realista por, no seu entender, responder a preocupações pessoais de seus autores em lidar com "perturbada consciência de pequeno-burgueses [que] imaginaram ter reformado o gosto, a sensibilidade e a imaginação." (BETTENCOURT, 1999, p. 11). Helder tão só destaca nesses movimentos literários a ausência de entusiasmo em afrontar os velhos valores, preocupados em pactuar com consciência ora de culpa ora de frágil consolidação de valores políticos oposicionistas com expressão consequente: “(...) a Presença era provinciana, académica de certa maneira, anti-revolucionária com certeza." (BETTENCOURT, 1999, p. 10). A ambos estes movimentos, em contenda, critica a atitude de resistência a postura moderna e europeia contrária ao revolucionarismo "órfico", o qual entende ser apenas continuado em criação poética de Bettencourt por este, como marginal a outros grupos ou escolas literárias, reparar o quanto se desligava: “(...) do narrativismo presencista, tão evidente sobretudo em José Régio e em Miguel Torga (...)" criando poesia "mais profunda, complexa e densa." (BETTENCOURT, 1999, p. 16-7) justamente em época coeva à da cultivada pelos autores de Presença. Helder acaba por identificar a falta de oportunidade de gerações literárias posteriores às do grupo de Orpheu para prosseguir na senda da modernidade, auto-classificando-se como suas herdeiras capazes de revolucionar a criação literária e cultural de Portugal dos anos sessenta. Compreende-se que recorra a Eduardo Lourenço em cujo artigo intitulado: 
"Presença ou a Contra-Revolução do Modernismo Português?" inicialmente escrito em 1958 e vindo, apesar de ter sofrido alterações, a ser publicado em 1961 em Rio de Janeiro no no 23-4 de Revista do Livro - Órgão do Instituto Nacional do Livro - a posteriormente integrar volume III: "Tempo e Poesia" de Obras Completas de Eduardo Lourenço (LOURENÇO, 2016, p. 778). Helder só podia estar de acordo com Lourenço quando este mais valoriza obra poética de criadores ligados a Orpheu, por nestes ver o culto da modernidade como escrita em forma-de-tédio que configura modo caótico da existência coeva ao assinalar a "irrupção frenética de ritmos, formas, objectos insólitos do mundo burguês em plena expansão ou explosão histórica" (LOURENÇO, 2016, p. 158) - sem todavia, como ilustrado com Pessoa-Campos, se deixar de visar "regresso à oculta Unidade" (LOURENÇO, 2016, p. 159), por se marcar "o frenesi mesmo (...) a teatralidade essencial desse êxtase, face histérica de um tédio visceral e inafundável." (LOURENÇO, 2016, p. 158).

Os poetas de Orpheu, mais que os presencistas, traduzem a inquietação própria de quem não assimila, distintamente, entidades divina e demoníaca como Lourenço explicita: "O universo de Orpheu é o de um abalo radical (...) confunde na terra desolada os deuses e os demónios." (LOURENÇO, 2016, p. 60) enquanto prossegue na "Procura (...) da sua própria realidade e da Realidade" (LOURENÇO, 2016, p. 60). O grupo de Presença não conseguirá consolidar a modernidade de Orpheu seguramente por não conceber espaço e tempo em poesia como, por exemplo, PessoaCampos o faz, providos de carácter singular e original com que "imagens triviais e mesmo grosseiras realizam a mais insólita das alquimias e instituem uma profundidade metafísica" (LOURENÇO, 2016, p. 159). Esta nova, rara e quotidiana linguagem trazida para o discurso poético contribuiu para representação transfigurante do mundo (LOURENÇO, 2016, p. 149) fazendo jus à experiência «tumultuosa e transparente do mundo moderno» para leitor aceda a "outro mundo" - quiçá o da alma do mundo através da sua própria (LOURENÇO, 2016, p. 149). Não vê Lourenço o psicologismo cultivado pelos presencistas como ferramenta ou testemunho operativo recuperado do instrumentário de Orpheu precisamente por respectivo revolucionarismo estar tão somente também na criação de realidade no seio do próprio poema, sendo os seus tempo e espaço anteriores aos do real exterior (LOURENÇO, 2016, p. 146; 156); explicar o fenómeno de Orpheu com base no psicologismo contraria a 
percepção do fenómeno literário moderno, o qual, segundo Lourenço, releva de "o caso da consciência imersa no mundo que a linguagem traduz. (...) O ser deste poetar é a consciência do drama da realidade mesma(...) agonia da poesia como lugar do combate por essa realidade." (LOURENÇO, 2016, p. 147). Imagismo conseguido pelos criadores de Orpheu, não remeterá para os referentes esperados; é expressão de sujeitode-consciência igualmente não referenciável, continuando exemplo de criadores modernos do século XIX francês, como Mallarmé (1842-1898) e Rimbaud (1854-1891), inovação confessadamente ignorada por presencistas como também denuncia Eduardo Lourenço (LOURENÇO, 2016, p. 156). A linguagem revolucionária reconhecida, quer por Lourenço quer por Helder, enquanto património legado por criadores de Orpheu, distingue-se por sinal da perfilhada pelos autores de Presença; aqueles queriam erigir uma nova classicidade - i.e. paradigma de nova consciência da "experiência do Nada" partilhada com poesia universal por sujeito criador moderno -, distanciando-se de realidade de referentes e aproximando-se de configuração de uma forma, ela própria espaço de realidades objectuais inéditas patentes em dramatização poética. O poetar de Orpheu transforma o poema em espaço de experiência universal, combatendo por realidade cuja dramatização baseada em profunda ironia confere ao confronto empenhado do receptor o papel principal para que a agonia subjectiva/pessoal do poeta não tolde o horizonte da realidade no poema sob perspectiva contrastiva de irrealidade do todo comum (LOURENÇO, 2016, p. 147-8; 151; 153). A moderna poesia, que a dos presencistas não conseguia ser, realiza-se pela forma, segundo Lourenço; faz por vozes, pelas quais o sujeito poético não fala de si ou do mundo, mas,através da inabalável distância, faz-se outra sua voz (LOURENÇO, 2016, p. 150) - sob toada de influente imaginação universalmente identificável. A realidade só o é enquanto gerada em obra; sendo assim criada, e, sendo nova, moderna e insólita, desvela-se como experiência havida em alma do sujeito moderno recobrada por linguagem composta iluminando "a anulação épica da realidade", representando concomitantemente complexidades e desumanidades sob ritmo tão frenético quanto o configurado por qualquer destinatário: “Os poemas de Orpheu traduzem uma tal ausência de nós em conflito de todos e de ninguém. $\mathrm{O}$ verdadeiro real não está em parte alguma: nem no homem como consciência, nem no universo como 'em face' dessa consciência. $\mathrm{O}$ 
drama reside nisso, é disso que os poemas são feitos." (LOURENÇO, 2016, p. 151). Tal significa tão somente que a realidade criada é tão irrealista quanto não-figurativa - por nela o receptor não identificar elementos estáticos plenamente reconhecíveis, mas sim processos dinâmicos inerentes a estas imagens irrealistas, remetendo para imaginação fulgurante patente nesta forma, a "exterioridade", dirá Lourenço, como passagem para o poema que a si "próprio se gera não só pela história, pela linguagem, pelo inconsciente activo que o promove, como pela arquétipa imaginação nossa que o recria." (LOURENÇO, 2016, p. 157-8). Esta é prova, segundo a qual a realidade única existe sendo prévia à trivial: sendo-lhe inerente o provocar o confronto com concepções de espaço e de tempo comummente aceites para chegar à compreensão de novas noções de ambos, conferindo ao poema discurso para tomada de consciência da sua relação com o mundo e consigo própria (LOURENÇO, 2016, p. 149). Deste modo interpelado, o receptor desta poesia moderna confronta-se com nova consciência, tornando-se simultaneamente espaço de trágicas irrealidades à medida que se conquista como moderno actor-interventor:

O arlequim (...) emblema desta geração funambulesca e audaciosa. Ele dança sobre a sua própria cruz e esssa dança reabsorve o horror ao mesmo tempo que o exalta por contraste. É essa dança anímica que nos torna íntimos Sá -Carneiro e Pessoa e dá aos seus poemas um optimismo trágico. (LOURENÇO, 2016, p. 155)

Afastando-se de si próprio, acolhe pelo poema a distanciação promovida por este para potenciar a ironia - inidentificável com a semiironia, o sarcasmo ou a sátira de presencistas como as seguidas em Régio ou a invectiva e apóstrofe cultivadas por Torga como refere Lourenço: “A ironia de Pessoa traça o movimento mais libertador e anónimo da sua poesia. O sarcasmo, a semi-ironia, a sátira de Régio, tais como a apóstrofe e a invectiva de Torga são a ferida deles antes de ser a nossa." (LOURENÇO, 2016, p. 153) - ficando à mercê da sincera insinceridade ${ }^{2}$ definida por Pessoa e que nos românticos alemães poderá assumir a "potenciação qualitativa" (qualitative Potenzierung) definida por Novalis. ${ }^{3}$

\footnotetext{
2 Em "Nota ao Acaso" in Sudoeste, (n⿳03, 1935) atribui Pessoa "grandeza" a Shakespeare à "constante insinceridade", patente na obra "essencial e estruturalmente factícia" do poeta inglês (Pessoa 1986 a:236), a qual acabava por resultar na soberanamente admirada "constante sinceridade".

${ }^{3}$ Novalis em Fragmente und Studien (1797) definia já essa união dinâmica essencial entre opostos própria da filosofia da Romantik: “O mundo tem de ser romantizado. Assim se encontrará de novo o sentido original.
} 
Ausência de distância, experiência de nada real, assim define Lourenço a aventura moderna de Orpheu, que a ancilose "contra-revolucionária" dos presencistas não soube potenciar; a respectiva "revolução poética" também justificadamente constatada por Helder em Bettencourt cuja defesa por Lourenço, Helder aplaudiu -, faz-nos compreender melhor o quanto ao poema moderno não se ajustam "descrição, comentário, alusão, símbolo ou sugestão", tão só porque a original realidade é erigida em poema inédito (LOURENÇO, 2016, p. 146).

\section{3: O PRÓPRIO HERBERTO HELDER, EM OBRA DE 1979 INTITULADA PHOTOMATON \&VOX, une de modo singular teorização e criação poética. O} estilo ensaístico presente na maior parte dos textos não prescinde de imagens ou metáforas para tornar vivamente poética a defesa da sua arte poética. Seguiremos por esta obra em coerência com o analisado em supramencionados artigos, para melhor se recolha matriz da essência da modernidade na criação poética perfilhada por Helder. Sempre prático, em "(feixe de energia)" de toada poetológica sob organização ritmadometafórica do discurso, Helder define poema não como representação ou narração por diacronia de objectos e coisas exteriores ao criador, mas como núcleo de energia com "poder de alimentação" resultante da oposição dramática entre contrários-de-emoção que ganham voz - pressupondo a teorização romântica chegando posteriormente a referir Novalis (HELDER, 1979, p. 148): “Porque o que se vê no poema não é a apresentação da paisagem, a narrativa de coisas, a história do trajecto,/ mas/ um nó de energia (...)/ um modelo fundamental de poder,/ de alimentação/ (...) /poesia, vociferação/ comovida; isto é uma força, o meu fulgor no escuro, (...) “(HELDER, 1979, p. 144-5).

Mantendo o mesmo registo de discurso ensaístico-poético, Helder prossegue por prosa - e por verso igualmente - em "(guião)" com a explicitação de poema - com metáfora emprestada já não à electricidade, mas às ciências naturais - comparando-o a uma paisagem cujo movimento tanto lhe é exterior como interior, reiterando assim a tensão e a dinâmica entre pólos opostos constituintes do "tema secreto ou seja: a acção

Romantizar nada mais é que uma potenciação qualitativa. Por esta operação, o Eu-inferior identificar-se-á com um melhor Eu. Tal qual nós próprios fazemos parte de uma sucessão qualitativa de potências. Ao conceder um sentido superior ao trivial, um carácter misterioso ao vulgar, ao conhecido a dignidade do desconhecido, ao finito a aparência do infinito, estou a romantizar."

https://www.br.de/radio/bayern2/sendungen/radiowissen/deutsch-und-literatur/novalis-dergeheimnisvolle-weg100.html 
mobilizadora" (HELDER, 1979, p. 146) constituinte de poema enquanto "máquina" cuja vitalidade assente no espírito, faz respectivo discurso espaço de todas as arbitrariedades comprovando quanto a existência do acaso segue a par e passo as manifestações da imaginação do criador moderno consciente da igualdade entre poema e animal; Helder não reconhecendo a existência do poema em função do leitor, toma-o espaço de sortilégios, pelos quais se esconjuram espíritos, emoções, inconsciente como refere em "(memória,montagem)" (HELDER, 1979, p. 152), cuja realidade se sobrepõe à realidade empírica conferindo-lhe existência justamente pelo modo como organiza e compõe os elementos-coisa com significação tornada simbólica como dilucida em "(imagem)":

O propósito do poema é esclarecer-se

a si próprio e, (...) tornar viva a

experiência de que é o apuramento e a intensificação.

O poema inventa a natureza, as criaturas as coisas, as formas, as vozes, a corrente magnética que unifica tudo num símbolo: a existência. (HELDER, 1979, p. 150)

O poema acolherá da experiência as marcas de mundos: exterior e interior e, organizando-as, proporá uma decifração enquanto instrumento de 'cultura', cuja missão Helder define em "(Nota Pessoal)" como "esse labor de expor formas e decifrações (...)" (HELDER, 1979, p. 124) que, lutando contra a "moral da imaginação" , como prossegue agora em "(vulcões)", dá voz a contradições, acumulando-se em interrogações configuradas em discurso condensado por conotações, alusões, descontinuidades, legibilidades abertas e incompletas de que só símboloenglobante poderá dar conta (HELDER, 1979, p. 131; 150). O poema tornase metadiscurso, no qual nem sentimentos nem pensamentos serão determinantes para o esclarecimento. Poderá a linguagem poética esclarecer a 'cultura'? A ideologia, a mitologia, a psicologia, a linguística são inoperativas face à exegese inclusa no poema; já o contrário é tão só verdadeiro, desde que, tal como Helder em "(imagem)" sublinha, aconteça tal de modo acidental (HELDER, 1979, p. 150). Poema é instrumento para mergulhar "na 'coisa' que está nas coisas" como volta a definir em "(guião)"; o acto poético apresentará ao leitor experiência de intimidades objectiváveis em forma de mito, conferindo assim à linguagem a forma de encenação de discurso, no qual ironia e ambiguidade prevalecem, para que 
"visão pessoal do mundo" tenha, de modo absoluto, o poder imperativo tão avassalador quão revolucionariamente estruturante da realidade (HELDER, 1979, p. 147-8). Mas a realidade, da qual o poema emerge, não é, para Helder, mecanicamente quer talentosa quer verdadeira. A palavra escrita - a ser dita - passará a ostentar essas singularidades se símbolo através de si configurado for criado e este conceder a sistema de sinais o poder de sensibilização e persuasão que lhe creditem existência tão viva quanto a de universo por onde vogam os sonhos; também Helder toma estes como propulsionados por energia do inconsciente reconhecendo ao discurso onírico capacidade exegética superior à dos instrumentos ortogonais racionalizáveis; a realidade apresentada em poema é por isso mais viva, porque mais real, gerando enigma sobre enigma ironicamente até infinito (HELDER, 1979, p. 59). Do mesmo modo que a linguagem dos sonhos se verterá em imagens difusas, inusitadas, insólitas, bizarras, se reportando a arqui-experiências e cravando-se no cerne da realidade, também a linguagem poética da modernidade só terá de lhe seguir pista e senha: "A experiência é uma invenção" como lapidarmente - e quase inocuamente - destaca Helder em "(os passos em volta, apresentação do rosto)" (HELDER, 1979, p. 73). A escrita é, tanto quanto a experiência, invenção; mas também, sendo experiência e simultaneamente invenção, ilustra quanto a ironia utilizada até infinito serve para se perceba a falibilidade da verdade literariamente proposta como real, donde se salientará o poder da energia como fonte de movimento perpétuo, gerado pela contradição em seio de discurso cerradamente organizado em texto poético fechado sobre si próprio e simultaneamente aberto para fora de si próprio:

Relatos de sonhos (...) tornam-se mais seguros que relatos de acontecimentos. (...)

Recorri à parábola, à alegoria, à metáfora. A realidade do registo é garantida pela convicção

das hipóteses, pelo tecido plausível dos enigmas. (...) Referências a objectos, situações, movimentos, aparecem como imagens ou metáforas de experiências muito antigas, como elementos da composição interior, portanto: do mundo, da vida. (...) Poderia escrever cem relatos diversos.(...) Mas seriam verdadeiros, por serem todos uma invenção viva. (...) Mas devemo-nos munir sempre de uma ironia que coloque dubitativamente a nossa mesma proposta. (HELDER, 1979, p. 72-4). 
Helder considera a experiência na criação poética moderna superior à experiência que lhe deu origem: aquela, mais real, traduz ordenação construída através da linguagem estruturante do caos inicial; o verbo impor-se-á como factor decisivo para dar forma a enigma em sucessão que nasça de ritmos ${ }^{4}$ apreendidos no mundo, com o qual o criador moderno interage. A forma adoptada replica o ritmo da experiência no mundo de cujo sentido tanto mais se aproximará o receptor quanto aceitar nova interrogação, decifração, enigma. A metáfora da "escada apenas para subir", utilizada em "(galinholas)", (HELDER, 1979, p. 127) elucida claramente esta concepção da linguagem utilizada na obra de arte literária moderna ${ }^{5}$ como bem pertinente: a linguagem, a forma adoptada, vale enquanto souber gerar "novos problemas", refere-o em prosa de "(nota pessoal)" (HELDER, 1979, p. 124) por muito que a respectiva significação em momento da sua apresentação não seja ainda pertinente, mas se distinga pela capacidade de persuadir o interesse de destinatário. De metáfora em metáfora a significação ganha cada vez mais distanciamento face à realidade referencial, revolucionando o modo de agir sobre esta à luz da inteligência que o caminho através da obra de arte literária aperfeiçoa via construção metafórica (RIBEIRO, 2019, p. 311). Será ocasião, na qual o tempo se tornará espaço, no qual a "obsessão mestra" patente no poema se desenvolverá, tornando-se este discurso composto por pequenas unidades em sucessão como se de uma realização cinematográfica se tratasse e cujo ritmo seria o elo-de -ligação entre esses instantâneos que provocarão no receptor esse vaivém constante entre realidade empírica e realidade poética assim revivificando simultaneamente a memória remota enquanto ao papel da imaginação durativa concede singular importância através da montagem de instantes, de que o criador poético moderno é autor. Neste particular, Helder elege a

\footnotetext{
4 "E vós, ó coisas navais, meus velhos brinquedos de sonho/ Componde fora de mim a minha vida interior!/(...) Fornecei-me metáforas imagens, literatura,/(...) Minhas sensações são um barco de quilha pr'ò ar (...) E a tessitura dos meus nervos uma rede a secar na praia !" - dá Campos ritmo livre à palavra em "Ode Marítima" ao realizar teoria poética de "foco dinamogéneo", o artista não-aristotélico, por via de cuja "sensibilidade" se "torna um foco emissor abstracto e sensível que force os outros (...) a sentir o que ele sentiu (...)", para realizar essa modernidade (PESSOA, 1986a, p. 233).

${ }^{5}$ Anotemos, de Tractatus Logico-Philosophicus de Ludwig Wittgenstein, a proposição: "6.54: My propositions are elucidatory in this way: he who understands me finally recognizes them as senseless, when he has climbed out through them, on them, over them. (He must so to speak throw away the ladder, after he has climbed up on it.) He must surmount these propositions; then he sees the world rightly." que deixa claro quanto em 1922 já o espírito da modernidade ganhava a forma, pela qual, mais de meio século mais tarde, Helder queria a moderna palavra enriquecesse a sua poesia como deixa programaticamente ilustrado - e assim vimos sublinhando na senda do respeito pelos modelos adoptados.
} 
metáfora do cinema para dilucidar por prosa poética em “(memória, imagem)" o papel do tempo:

Eu penso que a memória entra pelos olhos (...) porque Poe falara dos poemas instantâneos ligados por faixas verbais mortas. (...) Rimbaud partiu de todos os seus lugares (...) e fez no poema presente a montagem do poema ausente; (...) Qualquer poema é um filme e o único elemento que importa é o tempo, e o espaço é a metáfora do tempo, (...) Não existe outra metáfora que não seja o espaço; aquilo a que chamam metáforas são linhas de montagem narrativa, o decurso da alegoria, o espectáculo. (HELDER, 1979, p. 152-5)

E o poema em Helder torna-se forma, na qual "ritmo orgânico" age sobre a memória e provoca a expressão do imaginário que se desdobra em metáfora sobre metáfora geradora de enigma sobre enigma cuja decifração será acolhida por receptor instado pela energia multiplicada via imaginação ${ }^{6}$. O poema virará revolucionário, porquanto as "legibilidades" potenciáveis afrontam qualquer polícia ideológica ou estética por recusarse a manipulação gramaticalmente escorreita e funcionalmente pragmática: a significação não resiste à sugestão por ritmo, forma flectida em fluir da linguagem; perdem a preponderância os conteúdos explícitos e de imediata inteligibilidade, ganham-na os provocados pelas flexões trabalhadas pelos ritmos, como atesta Helder em "(guião)": “(...) A forma lida renasce continuamente após cada leitura e permanece em equilíbrio no perigo de uma multiplicação de legibilidades." (HELDER, 1979, p. 145). E o movimento conferirá verdade a esta composição por a estratificação do tempo interior levar a um condensar de significações cujo fechamento contribuirá para o fortalecimento de discurso obscuro tal qual Helder define o discurso poético de Edmundo de Bettencourt, seu mestre, assim relembrado em "(lembrança)":

\footnotetext{
${ }^{6}$ E não é esta a "lição da modernidade" de Pessoa, ao apropriar-se, em pleno acto de fala, de linguagem trivial e se elevar como poeta moderno destacando singularidade denunciadora concomitante e respectiva imperiosidade estética ao preservar pela linguagem literária o fulgor-da-emoção imanente a cena de quotidiano, potenciando-o através de expressividade símplice e consolidante de universo-de-significação matricial? Recordemos B. Soares ou A. Campos flexões de Pessoa: moderno criador-fautor de sensações, i.e., "sensacionista", para quem "toda a arte é a conversão de uma sensação numa outra sensação." (PESSOA, 1966, p. 168), criando "realidade inteiramente diferente daquela que as sensações aparentemente do exterior e as sensações aparentemente do interior nos sugerem." (PESSOA, 1966, p. 191).
} 
(...) mestre, (...) perscrutador do nosso caos (...). É que as virtudes de Bettencourt (...). O pudor, a marginalidade, o silêncio, porventura mesmo algum gosto da obscuridade, deslocaramno do falatório cultural suplementar e outros empreendimentos tribais. (...) Foi um poeta (...) Desapareceu, mas é no seu desaparecimento que se nos concede aparecermos. Porque ‘o que fica os poetas o fundam'. (HELDER, 1979, p. 173-6)

O tempo como reduto da forma em que se esgota é simultaneamente chave-mestra para abrir e criar cifras ao longo do tempo a ritmo de significações, de interrogações sobre interrogações à medida que o criador literário vai ascendendo por escada-de-metáforas - sem interesse por passado- mas que enforme futuro de emissor e receptor. Assim o poema criará o próprio tempo próprio, afastando-se de qualquer realidade reconhecida ou reconhecível ou como Helder em "(galinholas)" também assinalou: "O que não significa agora vai significar um dia destes. Mas significará uma coisa bastante diferente." (HELDER, 1979, p. 127). O silêncio, uma das virtudes enaltecidas, na obra de Bettencourt, por Helder, será a pedra de toque condensando a distrinça face à velha modernidade: "Temos de aturar todo o aborrecimento de uma velha modernidade: Fernandos Pessoas, surrealismos, a política com metonímias, a filosofia rítmica, as religiosidades heréticas, as pequenas tradições de certas liberdades. Acabou-se." (HELDER, 1979, p. 128). Será o silêncio o anverso de que a obscuridade se constituirá verso, esse escopo de que a poesia moderna se fará lábaro para que o verbo volte a ser espaço da energia de que o corpo carece para não ficar atordoado pelas coisas da cultura e recuperar a vitalidade? O poema será a forma de preservar o silêncio? Através da palavra? O poema será para Helder forma utilizando a palavra para provocar o êxtase de que o corpo carece e será imprescindível para a poesia ascender a uma nova modernidade: "O corpo precisa de transe, de êxtase. Essa, a única significação. Há uma energia geral, com a qual o corpo não tem estado em contacto, por causa de uma quantidade de porcarias da cultura." (HELDER, 1979, p. 128) afirma ainda em "(galinholas)" interrogando-se se a poesia não precisará da a-referencialidade, da abstracção para inexoravelmente ascender a uma nova modernidade ${ }^{7}$. E

\footnotetext{
${ }^{7}$ B. Soares diz nada ser mais simples afinal que "fotografar em palavras" (frag. 130 PESSOA, 1982, p. 139) para se gere "palavrar" (frag. 15-PESSOA, 1982, p. 15): "Gosto de dizer. Direi melhor: gosto de palavrar. As palavras são para mim corpos tocáveis, sereias visíveis, sensualidades incorporadas. Talvez porque a sensualidade real não tem para mim interesse de nenhuma espécie - nem sequer mental ou de sonho -,
} 
Helder, agora em "(movimentação errática)", critica peremptório e lapidarmente: "O silêncio é que deveria ter sido o ponto de partida para a experiência pessoal da modernidade." (HELDER, 1979, p. 138) se é que pretende "repôr então o silêncio (...) e [aos] poemas cheios de honestidades várias e pequenas digitações gramaticais, com piscadelas de olho ao 'sr. real quotidiano'." (HELDER, 1979, p. 138-9) dizer: não. Mais que cotejar e/ou referir Rimbaud, Mallarmé, A.C. Clark, Leslie Fiedler, a Goethe, Hölderlin, Nietzsche, Breton, Sengalen, Hofmannsthal, Trakl, Pessoa, Sá Carneiro, Celan, Bataille entre outros, sempre com o propósito da fundamentação prática do seu travejamento teórico, Helder cita Jorge Luis Borges (1899-1986) para se perceba o quanto o proclamado em 1979, data de edição de Photomaton $\mathcal{E}$ Vox, ainda que repto à criação literária portuguesa coeva, significava o canto do cisne, porquanto em 1930 Pessoa ainda vivia - Borges já asseverava ser a literatura arte com capacidade para vaticinar e saber: "enamorar-se da sua dissolução (...) e encontrar o fim." (HELDER, 1979, p. 139). O penúltimo texto, em Photomaton \& Vox intitula-se "(a carta do silêncio)" (HELDER, 1979, p. 17883); logo em segunda linha desta prosa ensaístico-poética Helder interroga-se - retoricamente - "se a poesia não é uma prática para o silêncio" (HELDER, 1979, p. 178); e,através desta "Carta", dá a perceber como só o verbo estruturado em linguagem, qual 'pauta verbal', comporta o silêncio como estratégia literária moderna não para a palavra, mas para as suas "condições da ausência": "Sobre a forma que lucila em curtas e repentinas formas (...) pesa a mudez (...) as condições não são as da palavra, mas (...) da ausência." (HELDER, 1979, p. 179); maior a tensão gerada e inesgotável a energia oriunda do inconsciente esteticamente flectido em metáfora insólita e inédita ${ }^{8}$ e mais transformando o poema em trama enigmática de correspondências, deixando a referencialidade sem réplica, e fomentando simbolizações, mais "A imagem ganha é uma metáfora (...) símbolo do real" (HELDER, 1979, p. 179). Eis a razão, pela qual se considerará émulo de Bettencourt e membro de "modernidade" nova. Sempre dilucidando, Helder explica como este silêncio é projecção de voz

transmudou-se-me o desejo para aquilo que em mim cria ritmos verbais, ou os escuta de outros (...)" - cf. http://arquivopessoa.net/textos/4520; a criação estética nasce discurso literário ao assimilar actos-de-fala, através de cuja apropriação o sujeito, des-contextualizando (1) e re-contextualizando (2) à luz de distanciação respectiva, torna redivivas cenas ditas.

${ }^{8}$ A palavra moderna resiste mais ao tornar-se "muda" sendo forma para: "L'inconscient esthétique, celui qui est consubstantiel au régime esthétique de l'art, se manifeste dans la polarité de cette double scène de la parole muette (...)." (RANCIÈRE, 2001, p. 41) 
de outro - outronímico9: duplo cuja expressão radical só é mudez (HELDER, 1979, p. 181). Expressão radical, a mudez? Claro, a mudez: "silêncio oferecido por umas quantas palavras em voz rítmica, modulações sensíveis" (HELDER, 1979, p. 180) e só intelegível para outronímico disposto a ouvir a sua voz mais profunda e oposta à da cultura dominante - tal qual como por esta imagem Helder lhe dá expressão para significar o volte face literário que pertinente carta, que cita, atesta. Refere a respectiva autoria: Hugo von Hofmannsthal (1874-1929), o qual publicou seu ensaio "Ein Brief" entre 18 e 19 Outubro de 1902 em diário berlinense Der Tag para assinalar quanto - como agora Helder face a Portugal também faz - a época literária de viragem do século e verbo, em desgaste, precisariam do silêncio para fazer jus à voz do mais profundo outro emergindo pelo homem do século XX: "E agora é Hofmannsthal com a traqueia cortada, estilo de dizer que não sabe como dizer (...). Leio a carta suposta de Lord Chandos a Lord Verulam." (HELDER, 1979, p. 181). Esta "Ein Brief"10, ensaio de autoria de profícuo escritor austríaco de século XX - com repercussão mundial estendendo-se pela narrativa, lírica, drama, ensaio, libretti - acompanha a literatura da Viragem-do-século nas suas vertentes impressionismo, simbolismo e arte nova. Nela, Hofmannsthal reflecte, por via da distanciação usual na ficção própria de texto literário, sobre o modo moderno de a criação literária elevar o seu veículo de expressão: a linguagem, largando à criação literária tarefa de maior entendimento com a realidade moderna: "Sentia um inexplicável mal-estar só por pronunciar as palavras: 'espírito' 'alma' 'corpo'. Não me era possível, por disposição interior, emitir uma opinião profunda sobre assuntos da corte ou ocorrências no Parlamento ou sobre quaisquer outros que queira." (HOFMANNSTHAL, 1902). A questão fundamental: a utilização da

\footnotetext{
${ }_{9}$ E Helder e Bettencourt e Lourenço reconhecendo desde sempre ao sujeito poético - respigador obsessivo de outridade (frag. 230-PESSOA, 1982, p. 256) - humildade indispensável ao discurso da modernidade enaltecendo a "pessoa de outro", no qual se encenam "dramaticamente" acções dos vários "eus" de que aquele se sente voz (PESSOA, 1986b, p. 97).

10 "Ein Brief" ("Uma Carta") - datada de 1603,foi enviada por Lord Chandos a também par do reino conhecido por Francis Bacon (1561- 1626): Lord Verulam 1ํㅡㄴ Visconde de St. Alban, Attorney General de Ingaterra e País de Gales (1613-1617) e Lord High Chancellor de Inglaterra (1617-1621) sob reinado de James I e que se distinguiu sobremodo como filósofo empirista cujo pensamento está na base do método científico e cujos princípios em defesa do método experimental desenvolvidos em Novum Organum o distinguem como pioneiro do pensamento científico moderno.

a) 'Ein Brief' incluída em volume"'Essays, Reden, Vorträge" citar-se-á (HOFMANNSTHAL,1902) remetendo-se para 'link':

http://www.zeno.org/Literatur/M/Hofmannsthal,+Hugo+von/Essays,+Reden,+Vortr\%C3\%A4ge/Ein+Brief b) Todas as citações, de obras vertidas de alemão, francês e inglês por nós realizadas, são de nossa autoria.
} 
palavra até ao século XVII vinha servindo intuitos externos, porquanto de duvidosa fidelidade a linguagem lábaro das configurações capazes de revelar 'sentir'11 em homem da época moderna: "Perdi completamente a capacidade de pensar ou falar coerentemente sobre qualquer coisa." (HOFMANNSTHAL, 1902). O confronto entre garante de literariedade reconhecido por tradição literária, por temática e processos estilísticos e a procura de nova modernidade - pela fidelidade à verdade exterior representada por ficção literária - identificável com "mentira" levam Hofmannsthal a caracterizar personagem Lord Chandos como projecção do criador literário em momento de encruzilhada cuja tomada de decisão não mais pode ser adiada. Hofmannsthal contrapõe à palavra utilitária, servindo a descrição da realidade externa, a palavra ao serviço da realidade interior do criador potenciando a sua amplitude de ser 'homem completo' como Álvaro de Campos assevera em "Ultimatum". A “Carta” dramatiza -“E tudo isto é uma espécie de pensar febril, mas um pensar por meio de uma matéria, mais imediata, fluída, radiosa que as palavras. São igualmente como vórtices, mas que parecem não levar como as palavras da língua para o vazio, mas de algum modo para dentro de mim mesmo e para o seio mais profundo da paz." (HOFMANNSTHAL, 1902) - o desespero em forma de monólogo e tácito diálogo com o destinatário para vincar melhor a influência programática com vista à mudança de

\footnotetext{
11 "Ein Brief", carta e remetente factícios: Lord Chandos,com intuito maior: reflectir sobre o modo como o texto literário poderá superar obstáculos com séculos de tradição devido a abuso na vulgarização da palavra poética; por isso Hofamnnsthal convoca o seu leitor para se transfira para época de grande desenvolvimento técnico-científico de inícios do XX ao aludir-se a afastamento de movimento literário Naturalismo e denunciando a utilização da palavra por este na senda de fidelidades à realidade sociológica replicando método das ciências experimentais quase esquecendo a realidade individual psíquica, a que a palavra moderna também se ajusta para melhor traduzir a sensibilidade do homem coevo (GRIMMINGER, 1995, p. 186-8); mas também se refere distanciamento de tendências literárias pugnando por afastamento da realidade histórica na defesa da autonomia da arte literária: arte pela arte e respectivo enclausuramento do escritor em torre de marfim exercitando-se em artificialismos alienantes. Datando-se a carta, facticiamente: 1603, (princípios do Barroco e primórdios do Iluminismo Alemão) Hofmannsthal não pretende deixar ao acaso este detalhe prático: ao leitor, o retomar de peso da palavra em seio da literatura edificante e enciclopédica através de encenação demonstrativa, para compreenda melhor o drama do escritor moderno e a necessidade de revolucionar a criação pela palavra moderna: "Queria fazer a crónica dos primeiros anos do reinado do nosso glorioso e passado soberano Henrique VIII (...) Queria decifrar fábulas e narrativas míticas legadas pelos Clássicos como se tratassem de hieróglifos de uma sabedoria secreta e inesgotável. Recordo-me deste plano (...). Tinha a intenção de reunir uma colecção de Apophthegmata como os redigidos por Júlio Cesar (...). Tinha a intenção de conseguir colocar lado a lado os ditos memoráveis que pudesse reunir durante as minhas viagens e que fossem de autoria quer de homens cultos e mulheres sábias do nosso tempo com quem privei quer de pessoas singulares do povo quer de pessoas cultas e extraordinárias. Queria assim associar as belas máximas e reflexões extraídas das obras dos Clássicos e dos Italianos e o que mais encontrasse de espiritual rebuscado em livros, manuscritos ou discursos (...). A obra por inteiro ostentaria o título 'Nosce te ipsum'." (HOFMANNSTHAL 1902).
} 
paradigma na sequência do que Baudelaire já em meados do XIX defendia como urgente: a criação de uma nova "antiguidade" (antiquité) ${ }^{12}$. A dramatização é a desta época, durante a qual a existência embrionária do texto literário moderno se começa a delinear melhor. Sendo a palavra no seu uso objectivo ajustável a outro tipo de discursos, pelos quais a comunicação será mais conforme a objectivos pedagógico-históricoretóricos, haveria que, a partir desta era moderna, ganhar conviç̧ão quanto à nova forma a conferir à palavra, porque ajustável a outra realidade mais próxima da interioridade em descoberta no homem moderno: "Então parece-me que o meu corpo seria composto de simples cifras que me desvendariam tudo. Ou como se pudéssemos aceder premonitoriamente a toda a existência de um modo novo caso começássemos a pensar com o coração." (HOFMANNSTHAL, 1902). Chandos representa justamente o homem moderno cuja completude a ciência, debutante, não consegue explicar cabalmente. Por isso denuncia só não poder sair do desespero gerador do vazio dramático em que se encontra por ainda não ter conseguido vislumbrar a forma adequada i.e. $\mathrm{o}$ espaço, no qual se possa movimentar a realidade do homem, na qual a linguagem seja forma de translação assim criando nova existência literária e realidade estética modernas: "Trata-se então de algo completamente inominado e mesmo dificilmente nomeável que se me anuncia em tais momentos como que uma qualquer aparição de uma vida mais elevada eivada de uma torrente avassaladora, oriunda do meu meio circundante quotidiano, enchendo um receptáculo (...)" (HOFMANNSTHAL, 1902). Situação prática ilustra cabalmente o valor de encontros-revelação por o mistério suscitado ser de tal modo enigmático que sujeito, e autor, logo associam o seu significado a constituinte mítico da própria existência:

Afinal o que teria isso a ver com compaixão, com encadeamento racional do pensamento humano, se numa outra tarde sob uma nogueira encontrar um regador meio cheio ali esquecido por um ajudante de jardineiro e se este regador e a água dentro dele fica tenebrosa pela sombra da árvore, e um alfaiate voga à superfície desta água de uma margem sombria para a outra outra e se a concentração destas insignificâncias me provocam uma emoção carregada de tal presença do infinito desde a raíz dos cabelos até à ponta dos pés que

\footnotetext{
${ }^{12}$ Dirá Baudelaire em "La Modernité": "pour que toute modernité soit digne de devenir antiquité, il faut que la beauté mystérieuse que la vie humaine y met involontairement en ait été extraite." (BAUDELAIRE, 1863).
} 
gostaria de verter em palavras caso desse com elas (...) (HOFMANNSTHAL 1902)

O fatídico desespero - por não conseguir decidir-se a escolher caminho ilustrado pelo confronto com objectos ou situações tomados por insignificantes e captados ao longo da sua existência quotidiana - é chamada de atenção para significação cuja impregnação se assinala ainda que sem interpretação:

Cada um destes objectos e milhares de outros semelhantes, sobre os quais habitualmente um olhar com natural indiferença se desloca, pode, para mim, ganhar repentinamente num dado momento, sobre cuja ocorrência não tenho qualquer poder, um cunho superior e comovente para cuja expressão todas as palavras me parecem demasiado pobres. (HOFMANNSTHAL, 1902)

Aqui chegados, a existência e a realidade objectiva passam a ficar repletas de valor tão pessoalmente interior quanto de cariz universal, justificando assim a necessidade de encontrar língua capaz de responder a linguagem, transcendendo o conhecimento objectivo ${ }^{13}$. Por isso a 'Carta' convoca o valor da interioridade/emocionalidade como realidade de que a língua só poderá dar conta se se pautar por uma condição a conquistar em cada acto de criação literária: ser exercício constante de metalinguagem, revelando assim a riqueza semântica que a combinação metafórica ao dispor de criador - rejeitante de uso funcional da palavra - como exercíciode-imaginação potencia. O conseguido imagismo está por isso ao dispor

\footnotetext{
${ }^{13}$ Chandos revela o apreço pelo aporte simbólico com que a realidade é percepcionada pelo sujeito sentiente, o seu discurso dá voz ao escritor moderno para quem objectivo é: 1- deixar de ser uma praxis literária de raíz enciclopédica assente no escopo 'conhece-te a ti mesmo'; 2- visar antes dar forma ao potencial de significações latente na língua como forma adaptável ao magma de significações de que a linguagem é patência; 3- reconhecer o quanto drama em seio da consciência do homem incapaz de recuperar o rtimo de uma aurea mediocritas é apenas a parte menor (os valores sociais em causa debilitam a sua serenidade mal se sente ultrapassado pela realidade e o seu andamento frenético; nesta viragem do século, época de alucinante crise económica e social pré primeira grande guerra, o homem do século XX reconhece acontecer tanto mais novidade quanto mais a crise levava à cada vez maior versatilidade na representação do real em qualquer domínio da criação estética.); 4- levar à consciência do criador, demiurgo, moderno o valor de vórtex aglutinador de magma de imagens, perante cujo confronto homem moderno acabará por encontrar forma que dê expressão ao drama de sua tomada de consciência: "Tenho de Lhe revelar o meu íntimo, algo peculiar, um mau hábito, uma doença do meu espírito se quiser, se se sentir no dever de entender o facto me sentir separado por um abismo inalcançável tanto dos trabalhos literários que aparentemente tenho pela frente quanto daqueles que já deixei para trás e que me são tão estranhos e que hesito em chamá-los meus." - assim interpelava Chandos o precursor da ciência moderna e seu método experimental: Francis Bacon. (HOFMANNSTHAL, 1902).
} 
de capacidade criativa que, aplicado a qualquer língua, torna esta espaço de translação do mistério originado na realidade e potenciado artisticamene pela sensibilidade do homem moderno que perplexo perante visão da realidade proporcionada em extra-ordinários momentos de extâse apenas pretende dar forma a inédito silêncio: "porque a língua, na qual me fosse talvez dada a possibilidade não só de escrever, mas tambem de pensar e de cujas palavras também nem uma é de meu conhecimento, nem é a latina, nem a inglesa nem a italiana ou a espanhola, mas uma língua, pela qual as coisas mudas falam comigo e na qual talvez um dia na tumba, frente a um juíz desconhecido, venha a justificar-me." (HOFMANNSTHAL 1902).

\section{4: E 'MODERNO' DESTACADO DA REALIDADE GANHA SIGNIFICADO SIMBÓLICO}

por esse objecto inusitado provocar emoções tão secretamente remotas quão as libertas pelo sonho como assinala Bahr (1863-1934) cujas análise e interpretação se estenderão à exegese de obra moderna, por enigma de criação e natureza se representar translatamente: 'Littérature à rébus' (BAHR, 1892), levando criador literário moderno a vincular sensibilidade à fruição de obra em plenitude. Por 'moderno' significar criar símbolos para assinalar realidade objectual sensorial ciente da capacidade de respectivo carácter remoto daqueles para despoletar os sentimentos intentados por enigma, o contributo para o silêncio como processo gerador da escrita moderna (BAHR,1892). Sentido será deslocado de espaço-designificação lógico-dedutivo-trivial para espaço complexo, de perplexidades; provoca-se afastamento de enunciação individualsubjectiva e a enunciação em discurso sob ponderado processo de significação. Discurso literário moderno representará não o mundo sentido, mas respectiva multiplicidade "polifocal" (KIESEL, 2004, p. 25) ilustrando processo de autonomização de produção textual superadora de personalidade autoral (KIESEL, 2004, p. 130; 131; 133-4), incluindo até estratégia heteronímica. Até porque do sujeito moderno ausentou-se a unidade (BAHR, 1890) por ansiar renegar passado e ser presente por sentir anunciação de futuros tal a necessidade de verter estímulos exteriores em interiores: "das Außen zum Innen zu machen". (BAHR, 1890). Fulgor-daemoção desliga-se tanto de acto-de-fala, como de plausibilidade natural, transferindo-se para lugar inusitado: discurso literário, enquanto espaço de emoção estética, pela qual se investe leitor como factor activo (aktiver Faktor) do texto moderno (VIETTA, 2007, p. 32). A discurso literário na 
Modernidade, reconhece-se inteligibilidade latente: obra de múltiplos sentidos em simultaneidade (RICOEUR, 1969, p. 166) por se munir de imagens de uso universal para focalizar o ser, constituindo-as em universode-significado-em-potência (RICOEUR, 1969, p. 71-3), porque «potenciando» expressividade através de clarividência mediata-súbtil tornada «semelhança mesmo em entidades muito diferentes» - como diz Aristóteles em Retórica (1412a) - por exercício para cultivar "impertinência predicativa" (RICOEUR, 1989, p. 213-7). A este motivo de síntese-genial, ao instante, assiste a constituição de praxis metafórica para fazer-ver (RICOEUR, 1983, p. 299) em modo prático-intuitivamente plástico e criador de realidade inventada/imaginada e prospectiva (RICOEUR, 1983, p. 269-70; 275-7; 273), favorecendo-se em obra literária da Modernidade o outronímico em receptor e simultaneamento em emissor (RICOEUR, 1989, p. 226): 1- à realidade hodierna sob enfoque, o criador literário vai retirando estratos de significação vulgares à medida que, sob veste dessas metafóricas «impertinências predicativas» e insistindo em adesão práticointuitiva a inusitado processo de «implicações» de significação em cujo espaço de entendimento a fragmentação tem lugar de eleição (BARTHES, 2007 , p. 18; 35) sobre o real, faz emergir nova verdade-matéria franqueado o bordo da linguagem (AGAMBEN, 2003a, p. 17); 2- através de dispositivode-potenciação "inesgotável" (AGAMBEN, 2003, p. 63; AGAMBEN, 2005, p. 68) explorando prospectividades imanentes autónomas de escritor /leitor. Tal modo-de-ser-assim (So-Sein) (AGAMBEN, 2003, p. 61-2) verificase em obra moderna cuja singularidade se recolhe não a processo-detransferência - ou de deslocação (BARTHES, 2007, p. 16) - de imagens de espaço factual para ficcional - qual pseudonímia -, mas a espaço-deplausibilidade, no qual a linguagem literária da modernidade (BARTHES, 2007, p. 21) se assume - qual heteronímia (BARTHES, 2007, p. 24)- contrapoder por em tal espaço de concepção de « utopias de linguagem» ser concomitante a "transformação do mundo" (BARTHES, 2007, p. 21) permitindo o ter-lugar (Statt-Finden) (AGAMBEN, 2003, p. 19) provocando tanto mais "pasmo" quanto perplexidades derivarem de estética-porresiliência inserta em enigmas de linguagem através de inventiva metáfora in absentia (RICOEUR, 1983, p. 275-8). Assim assistirá, à arte, a "dignidade", porque "alma" (l'âme de l'art) em corpo-presente (élément variable comme son corps) dirá Baudelaire em "Le Beau, la Mode et le Bonheur" (Baudelaire, 1863), em cujas imagens Benjamin vê "observação 
de processos banais para aproximar deles o poético" sem que o poeta deixe de se verter em "novas máscaras" (BENJAMIN, 2006, p. 98) mantendo-se "incógnito" para que a palavra "prosaica e urbana" se instale no "centro da linguagem poética" da modernidade rejeitando alegorias ou ordens premeditadamente aceites (BENJAMIN, 2006, p. 100-1). Mas apenas isso mesmo: testemunho de memória tornada acto de luz: "fenda de luz", porquanto "a conversação das imagens" no seio da obra moderna "gera" a "ausência" do seu criador, exímio "com a potência das coisas", com as quais dá forma à matéria "des-materializando" como assinalámos em Helder para quem obra poética moderna é espaço de "silêncio" e "internidade" (HELDER, 1979, p. 183; 181; 182). E para quem o peso da "mudez" sobre a forma - "que lucila em curtas e repentinas formas" atesta as "condições da ausência" pela palavra porque a "imagem ganha é uma metáfora", na qual "vai o silêncio na fala aumentando até ao tamanho todo" (HELDER, 1979, p. 179-80). Helder retoma, por "a carta suposta de Lord Chandos a Lord Verulam" (HELDER, 1979, p. 181), a "dor" inerente ao silêncio - matricial para o escritor moderno e sua relação hierática com o existir; encantamento (Bezauberung), deixado por "aparição", objectualinfinitesimal (Nichtigkeit), presente em determinados momentos de quotidiano, e do despertar para a insuficiência da expressividade inerente à língua face ao "pensar" com o coração (mit dem Herzen denken), enaltece o culto do silêncio loquaz experimentado: "Nestes momentos, uma criatura mínima, um cão, um rato, um escaravelho, uma macieira raquítica, um caminho sinuoso de carros pela colina, uma pedra coberta de musgo (...)." (HOFMANNSTHAL, 1902). Geram ritmo traduzindo arroubos literários provocados por tal sucessão de "Estas criaturas mudas e por vezes inanimadas [as quais] erguem-se-me com tal completude, com uma tal presença do amor, que o meu olhar extasiado é incapaz de, à sua volta, dar com alguma coisa morta (...)" (HOFMANNSTHAL, 1902) apenas buscando, por tal "insignificante" forma, a essencialidade silente capaz de fazer replicar em receptor moderno a fonte daquele encantamento enigmático de inefabilidade infinita. Helder pensa por formas mais imediatas, fluentes, fulgentes, mais plenas-de-matéria adequáveis a linguagem prenhe de plausibilidades indutoras no sujeito de perplexidades face ao ter-lugar de "silêncio anterior à palavra" (LOURENÇO, 1973, p. 43): eis condição absoluta da poesia moderna. 


\section{REFERÊNCIAS}

AGAMBEN, Giorgio. Die kommende Gesellschaft. Berlin: Merve Verlag, 2003. AGAMBEN, Giorgio. Idee der Prosa. F/M: Suhrkamp, 2003a.

AGAMBEN. Giorgio. Profanierungen. F/M: Suhrkamp, 2005.

ARISTÓTELES. Retórica. Lisboa: INCM,1998.

BAHR, Hermann. "Die Moderne" em Moderne Dichtung. Monatsschrift für Literatur und Kritik. 1890. in https://www.unidue.de/lyriktheorie/texte/1890 bahr.html

BAHR, Hermann. "Symbolismus „em Die Nation. Wochenschrift für Politik, Volkswirtschaft und Litteratur. 1892. In https://www.unidue.de/lyriktheorie/texte/1892_2bahr.html

BARTHES, Roland. Lição. Lisboa: Edições 70, 2007.

BAUDELAIRE, Charles. Le Peintre et la Vie Moderne, in Le Figaro 26 e 29 Novembro e 3 Dezembro, 1863. In :

http://charles.baudelaire.perso.sfr.fr/LePeintreDeLaVieModerne/LePeintr eDeLaVieModerne1.php

BENJAMIN, Walter. A Modernidade. (J. Barrento ed.; tradução: J. Barrento). Lisboa: Assírio \& Alvim, 2006.

BETTENCOURT, Edmundo. Poemas de E. Bettencourt. Lisboa: Assírio e Alvim, 1999.

GRIMMINGER, Rolf. “Der Sturz der alten Ideale.Sprachkrise,Sprachkritik um die Jahrhundertwende", in Grimminger, R.et al. (orgs.), Literarische Moderne -Europäische Literatur im 19.und 20. Jahrhundert, R/Hamburgo: Rowohlt, 1995, p. 169-200.

HELDER, Herberto. Photomaton \& Vox. Lisboa: Assírio e Alvim, 1979.

HELDER, Herberto. Poesia Toda. Vol I. Lisboa: Plátano, 1973.

HOFMANNSTHAL, Hugo v." Ein Brief "( Brief des Lord Chandos an Francis Bacon) publicado em jornal berlinense Der Tag de 18. und 19. Outubro 1902. In: http://www.zeno.org/Literatur/M/Hofmannsthal,+Hugo+von/Essays,+Re den,+Vortr\%C3\%A4ge/Ein+Brief 
KIESEL, Helmuth. Geschichte der literarischen Moderne. Sprache. Ästhetik. Dichtung im zwanzigsten Jahrhundert. München: Beck, 2004.

LOURENÇO, Eduardo. Pessoa Revisitado. Porto: Inova,1973.

LOURENÇO, Eduardo. Obras Completas de Eduardo Lourenço -Vol. III Tempo e Poesia. Lisboa: Fundação Calouste Gulbenkian, 2016.

PESSOA, Fernando. Obra em Prosa de F. Pessoa, vol. II, Textos de Intervenção social e cultural. A Fiç̧ão dos Heterónimos. (organização, introdução e notas de A. Quadros) Mem Martins: Europa-América, 1986a.

PESSOA, Fernando. Obra em Prosa de F. Pessoa, vol. I, Escritos Íntimos, Cartas e Páginas Autobiográficas (organização, introdução e notas de A. Quadros) Mem Martins: Europa-América, 1986b.

PESSOA, Fernando. Livro do Desassossego por Bernardo Soares (prefácio e organização J. Prado Coelho), vol. I, Lisboa: Ática, 1982.

PESSOA, Fernando. Livro do Desassossego por Bernardo Soares (prefácio e organização J. Prado Coelho), vol. II, Lisboa: Ática, 1982a.

PESSOA, Fernando. Poemas de Álvaro de Campos, Lisboa: Ática, 1978a.

PESSOA, Fernando. Páginas de Estética e de Teoria e Crítica Literárias. (textos estabelecidos e prefaciados por G.R. Lind e J.Prado Coelho), Lisboa: Ática, 1973.

PESSOA, Fernando. Páginas Íntimas e de Auto-interpretação. (textos estabelecidos e prefaciados por G.R.Lind e J.Prado Coelho), Lisboa: Ática,1966.

RANCIÈRE, Jacques. L'Inconscient Esthétique. Paris: Galillée, 2001.

RIBEIRO, Fernando. "Praising Silence in the Modern Literary Artwork". In AAVV. Modernity, Frontiers and Revolutions (Maria Rosário Monteiro et.al. eds.) London : Taylor and Francis Group, 2019, p. 307-312.

RICOEUR, Paul. Le Conflit des Interpretations. Paris: Gallimard, 1969 .

RICOEUR, Paul. Do Texto à Acção. Porto: Rés, 1989.

RICOEUR, Paul. A Metáfora Viva. Porto: Rés, 1983.

VIETTA, Silvio. Der europäische Roman der Moderne. Munique: Fink Verlag, 2007. 
WITTGENSTEIN, Ludwig. Tractatus Logico-Philosophicus. London: Kegan Paul, 1922.

Recebido em 17 de junho de 2020

Aprovado em 11 de novembro de 2020

Licença: (c) (7) (5)

Fernando Jorge Oliveira Ribeiro

Professor Doutor em Literatura Alemã (1996) pela Universidade Nova de Lisboa, Portugal. Docente de literatura, cultura e tradução literária alemãs da Faculdade de Ciências Sociais e Humanas da Universidade Nova de Lisboa, Portugal. Investigador integrado no CHAM - Centro de Humanidades NOVA/FCSH - CHAM, Lisboa, Portugal.

Contato: f.ribeiro@fcsh.unl.pt

(iD): https://orcid.org/0000-0001-8345-5606 